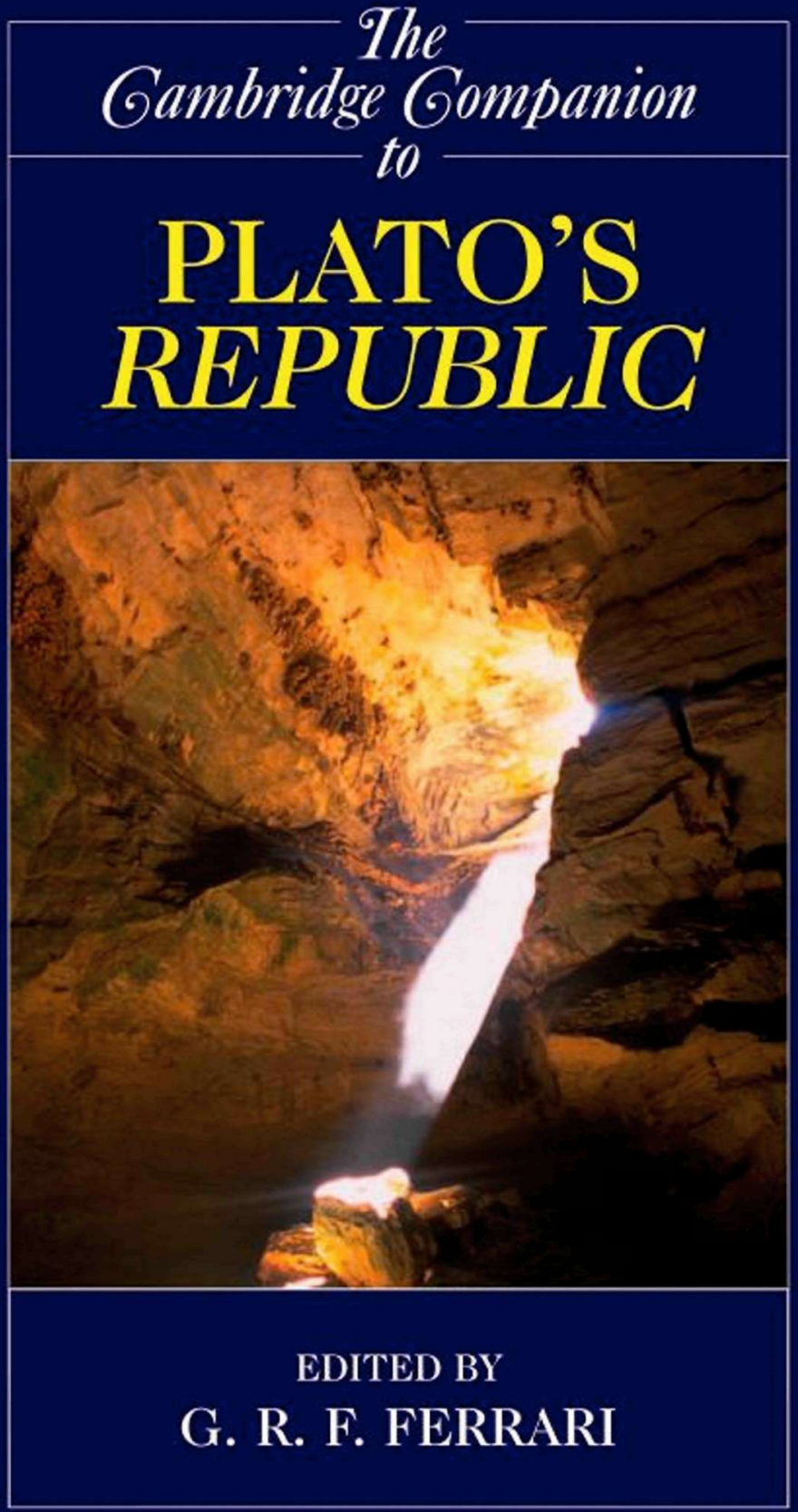




\section{Philosophy, the Forms, and the Art of Ruling}

\section{WHY PHILOSOPHERS ARE EQUIPPED TO RULE}

In his blueprint for an ideal society, the Socrates of Plato's Republic emphasizes three especially daring political proposals: first, inclusion of women in the guardian class, on fully equal terms with men; second, abolition of the family for this same elite class; and third, that philosophers should be kings. He speaks of these as three "waves" $(5.457 \mathrm{~b}-\mathrm{d}, 472 \mathrm{a}, 473 \mathrm{c}-\mathrm{d})$, with the final proposal, that of philosopherkings, heralded as the third and biggest wave within the "triple wave" (trikumia, 5.472a).

Quite how destabilizing these proposals are meant to sound can be appreciated only when we realize that Socrates is referring here not just to stormy waves but to a veritable tsunami of change. Not only have tsunamis been a familiar feature of Mediterranean history in both ancient and modern times, but eyewitness accounts of tsunamis - including the massive one in the Indian Ocean on December 26, 2004-again and again describe a sequence of three waves, an indication that it is this specific phenomenon that Plato is calling to mind. ${ }^{1}$ When Socrates speaks of a third and final wave as liable to "drown us in a deluge [katakluzein] of mockery and unbelievability" (5.473c), his reference is, if I am not mistaken, to a philosophical tsunami, a veritable cataclysm of incredulity that threatens to wash away his entire political agenda.

${ }^{1}$ Two passages from Athenian tragedy suggest to me an audience familiar with the tsunami phenomenon: (I) a giant wave ("with trikumia") preceded by an earthquake (Eur. Hippolytus II98-2I4) and (2) a triple wave preceded by the sucking down of the sea (Aesch. Septem 758-6r). Both these phenomena regularly precede a tsunami. I develop the theme in Sedley 2005. 
We should bear in mind too that a tsunami could, like that at Helike on the Gulf of Corinth in 373 B.C., ${ }^{2}$ be sufficiently powerful to wipe out an existing city and require its wholesale re-creation. In advocating the institution of philosopher-kings, Socrates shows himself well aware (7.540d-54Ia) that he is doing nothing less revolutionary than that.

Why then, despite the expected incredulity, should philosophers rule? Why, in Plato's Callipolis, does their privileged acquaintance with the transcendent Forms uniquely equip philosophers for the tasks of government? Socrates' answer is conveyed by one formal argument, followed up by a series of images. I start with a brief look at the argument, a famous and controversial one located at the very end of Book 5 (476d-480a). ${ }^{3}$

This argument is envisaged as addressed not to the Republic's philosophical interlocutors or readership but to an imaginary group of unphilosophical although culturally informed citizens who might well pride themselves on possessing knowledge, in an effort to persuade them that they have no such thing and should for this very reason put their welfare in the hands of philosopher-kings, who do. Characterized as "lovers of sights and sounds," they are in effect cultured individuals who seek to fill their lives with all manner of beautiful things, yet lack any understanding of the unitary essence of beauty, an essence that Platonically informed readers will equate with the Form of beauty, or "the Beautiful itself." Since members of this nonphilosophical intelligentsia have no awareness of any such transcendent entity, they are unlikely to accept initially that the philosophers have a stronger claim to knowledge than they themselves have. Nevertheless, they might yet be convinced, by a highly schematic mapping out of the relation of cognitive states to ontological realms that Socrates proceeds to develop. Beauty here will serve as no more than an example: the lessons about its understanding, when they emerge, will be readily extended to such concepts ${ }^{4}$ as

2 Strabo 8.7.I.55-2.4, 8.7.2.2 I-38; Pausanias 7.24.I 2.I-Io.

3 There is a large literature on this passage. For a reading radically different from the one adopted here, see Fine 1978, summarized and updated in Fine 1999a. Both articles are reprinted in Fine 2003.

4 I use "concept," here and elsewhere, to indicate the object or content of a conception. By calling a Form a concept, I do not mean to imply that it is merely that, i.e., that it has no being independently of being conceived. 
justice and goodness, which lie even closer to the core of the dialogue's argument. For even goodness, the very highest item in the Republic's metaphysical scheme and said to be "beyond being" $(6.509 \mathrm{~b})$, is for the philosopher a bona fide object of knowledge and definition $(7.533 \mathrm{~b}-\mathrm{c})$.

Knowledge, the nonphilosophers are first asked to agree, is of what is. There has been much scholarly dispute about the precise meaning of this last phrase, but for present purposes suffice it to say that in classical Greek usage "what is" typically expands into "what is something or other" (and not, for example, into "what exists"). Hence knowledge is of what is simply because, for any given subject $\mathrm{X}$ and predicate $\mathrm{F}$, you can know $\mathrm{X}$ to be $\mathrm{F}$ if and only if $\mathrm{X}$ is F. The same will apply even if the ". . is ..." proposition is not an ordinary predication but, for example, a statement of definitional identity. Hence knowing the definition of some Form, for instance, that (as argued in Book 4) justice is a certain interrelation of three parts, would be an excellent illustration of how and why knowledge is of "what is." (That this unqualified mode of being entails the subject's existence is not doubted by Plato, but that entailment is not enough to make the "be" in question existential in sense.)

Second, the nonphilosophers are expected to agree that "knowledge", an infallible power, is a cognitive faculty different from mere fallible "opinion" (doxa). Other cognitive faculties are distinguished from each other by having distinct objects - vision being of color, hearing of sound, and so on - and the same is taken to apply to knowledge and opinion. Hence knowledge and opinion are agreed to have different objects.

Although the inferential moves here $(5.477 \mathrm{c}-478 \mathrm{a})$ have rightly been regarded with some suspicion, the argument voices a deepseated conviction of Plato's. Since knowledge can by its very definition never become false, its object must be such as to be incapable of falsifying it, as it would threaten to do if it could undergo change. Therefore the object of knowledge is something incapable of change. Opinion, by contrast, being variably true and false, is inherently subject to revision, a feature that implies that its objects are, correspondingly, items that are liable to change.

What then are their respective objects? Since knowledge has already been agreed to be of what is, and since opinion cannot be plausibly correlated to what is not (which would correspond rather 
to a cognitive faculty or quasi-faculty that systematically achieves falsehood, "ignorance" as Socrates chooses to call it), the object of opinion must lie between these two extremes. Opinion, thus, has as its object whatever it is that "fluctuates between what completely is not and what completely is" (5.479d).

So far this is no doubt too abstract and schematic to shed much light on anything. But what the nonphilosophical aesthetes are meant to be now better placed to understand is the following. The kind of beauty that they pursue - that of beautiful songs, paintings, statues, and so on - is of an irremediably fluctuating kind. The same things that count as beautiful in one context, perspective, aspect, or historical period ${ }^{5}$ count as ugly in others. The aesthetes' evaluations are therefore subject to constant revision. Or, in the idiom of the current argument, "the many beautiful things" that they prize in fact fluctuate between being and not being beautiful. In other words, what "fluctuates between what completely is not and what completely is," the ontological class they have agreed to be the object of mere unstable opinion rather than of knowledge, turns out to match perfectly the very kind of object with whose pursuit they themselves are most concerned. Any aspiration they may have had to knowledge must be relinquished. Their chosen realm is one of shifting, perspectival opinion.

If only they understood the Form of beauty as well, they would appreciate that true cognition of it, in total contrast, is immune to such revision. When you come to know the essence or definition of beauty, you acquire understanding of an unchangeable truth that no more invites later revision than (Plato might say) your understanding of the properties of the number 2 could ever become out of date or inapplicable. What beauty itself is, it simply and unequivocally is. It is precisely by their detachment from the here and now, and their intellectual gravitation to the realm occupied by the changeless Forms, that philosophers gain cognitive access to Being, thus exercising the only faculty that can correctly be called "knowledge." The nonphilosophers do not know what they are missing, since they have

5 At 5.479a-b the argument fails to specify these and other ways in which opposites are liable to be compresent, but readers were no doubt expected to be familiar with them from other dialogues, notably, from Symposium $2 \mathrm{IIa}$. There again the example is beauty, for whose cultural instability cf. $4.424 \mathrm{~b}$ (quoting Homer, Odyssey I.35 I-52) with Adam I963 [I902] ad loc., 452c, Laws 66ob. 
never themselves distinguished Forms from their sensible instances. Nevertheless, the formal argument is meant to be sufficient to persuade them that they do not after all possess knowledge.

But why would this knowledge of unchanging Forms be the relevant kind of understanding required for administration of an entity, such as the city, that is inherently subject to change? The problem is exacerbated if the argument is taken to imply that, since knowledge's objects are limited to things incapable of change, the city's affairs are not even in principle capable of being "known." On such a reading, you can "know" what justice is, but no one, not even a philosopher, can comparably "know" that this or that policy is just, given only that in some circumstances or from some point of view that same policy is also unjust. This restriction of "know" may sound like a merely linguistic reform on Plato's part, but it is in reality much more than that, for it underwrites Plato's enterprise, central to the Republic, of radically reconceiving who or what a real political expert is.

Hence, although it is understandable that scholars have sometimes sought to rescue Plato from commitment to the implication that particulars cannot be known, ${ }^{6}$ it will prove not only safer but also ultimately more enlightening to embrace that implication. For in both reflecting and developing Plato's two-world metaphysics, such a thesis throws light on a tension in Plato's thought that will take center stage in the second half of the present chapter: on the one hand, knowledge is essentially unworldly, and is best exercised and enjoyed by philosophers operating altogether outside civic structures; on the other hand, the proper running of the civic structures themselves vitally depends on those who possess the

${ }^{6}$ This alternative has been best defended by Fine (references in note 3). She opposes the "two worlds" interpretation that I am assuming and according to which knowledge and opinion are distinguished primarily by their objects, and instead holds that they are distinguished by their contents: knowledge's contents are always true, opinion's can be true or false. It seems to me that the objects analysis is strongly supported by the ensuing cave simile, where cognitive states are in effect defined by their objects. Fine and others have pointed out that at $520 \mathrm{c}$ the philosophers returning to the cave are told "you will know what the individual images are and what they are of," but this is weak evidence because Socrates is here engaged in using the idiom of the cave simile (cf. an immediately preceding reference to "darkness"), and not his preferred epistemological vocabulary. In a more technical passage such as $484 \mathrm{c}-\mathrm{d}$, one that capitalizes directly on the Book 5 argument, he seems careful to limit the good politician's "knowledge" to that of Forms. 
knowledge being willing to apply it to the city's administration. For despite the fact, noted above, that in Plato's eyes you cannot, even in principle, "know" that a given policy is just, your ability to arrive at the (temporarily) correct "opinion" that in current circumstances such a policy is the most just will depend on prior knowledge, namely, your knowledge of what justice itself is.

Exactly how philosophical knowledge is meant to inform political activity is illuminated only when we move on to the celebrated similes in Books 6 and 7, of which I focus on two in particular.

Take first the simile of the Ship of State $(6.487 \mathrm{e}-489 \mathrm{c})$. The philosopher in existing society - exemplified here by a thoroughly Athenian-sounding democracy - is compared to an expert navigator trying in vain to make his voice heard on a ship where the crew (representing demagogues) have taken control, after drugging the rather deaf and short-sighted captain (the "people" or demos). These sailors flatly deny that navigation is an expertise, and they deride the expert when he insists that knowledge of winds and stars is required if one is to sail a ship correctly. They dismiss him as a mere "sky-watcher and chatterbox" (488e-489a, 489c). This derisive description echoes a phraseology that Plato's Socrates elsewhere uses with implicit approval (Crat. 40Ib7-9, Phdr. 270aI; cf. also its use at Pol. 299b), thus appropriating and turning to his own advantage the charges that were to be brought against him at his trial (cf. Apol. $\mathrm{I} 8 \mathrm{~b})$. We are thereby invited to recognize in the expert navigator a thoroughly Socrates-like figure.

This expert's understanding of the stars, contrasted with the sailors' scornful ignorance of them, represents a gulf in communication between philosophers and the rest of society that Plato in the Republic seeks to display at its starkest, as a first step toward its eventual bridging. There can be no possible doubt that the stars in the Ship of State simile symbolize the Forms. And just as the stars with their unfailing regularities are, unbeknown to the crew, vital to the navigation of the ship, so too in Plato's eyes it is only by reference to absolute and unvarying values, equated as usual with Forms, that an intrinsically unstable entity like the city can be well regulated. ${ }^{7}$

The same point is further elucidated by the cave simile that opens Book 7. Its main epistemological lesson lies in the following contrast.

7 Cf. 7.52 ra on the need for "a single aim" in those who govern a city. 
On the one hand, there are the bound prisoners in the cave, whose exclusive reliance on shadows cast by statues and other manufactured objects that are themselves artificial images of beings in the outside world represents the level of understanding found in ordinary citizens not only of a nonideal city like Athens, but also of the hypothesized Callipolis. On the other hand, there is the philosopher who, following his release, has absorbed the reality of the outside world before returning to the cave. Although (a point I shall develop shortly) this returning philosopher is initially portrayed as a Socratic figure, uniquely achieving enlightenment in a nonideal city and rewarded for his pains by the uncomprehending hostility of his fellow citizens, he becomes in due course emblematic of the class of philosophers whose education the ideal city promotes, orchestrates, and values.

First, why are the chained prisoners described by Socrates as "like us" (5 I5a)? Their epistemological state unmistakably matches the one Socrates has earlier called "conjecture," "fancy," or "imagination" (eikasia, 509d-5IIe), which amounts to basing one's experience on mere images of sensible particulars that are themselves mere images of Forms. Why are "we" like that? Don't we have innumerable daily experiences of sensible objects themselves, unmediated by their images? The answer to this old puzzle ${ }^{8}$ lies, I believe, in the first sentence of Book 7: the cave is to be an allegory, not of our general cognitive state but of our educational state ("our nature as regards education and lack of education," 5I4a). It is educationally, then, that we all are, or at any rate start out, like the prisoners. Our woeful distance from fundamental truths could be illustrated in terms of mathematical education, as the mathematical focus of the ensuing educational program encourages us to do-see especially $7.532 \mathrm{~b}-\mathrm{d}$, which insists that the entire process from the prisoner's first release to his looking up to the objects casting shadows outside the cave describes mathematical education. Nothing in the text suggests that such a reading exhausts the simile's meaning, and the references to education in general as its scope (7.5 I 4a) and to shadows of statues of justice $(7.5 \mathrm{I} 7 \mathrm{~d})$ are among many pointers that suggest

${ }^{8}$ An outstanding recent study of the cave, Wilberding 2004, uses the need to solve this puzzle as a starting point for a radically new interpretation of the entire image. I cannot here address his interpretation, but I believe that the very simple solution I offer to the puzzle makes the reinterpretation at any rate unnecessary. 
the contrary. Nevertheless, mathematical education is undoubtedly one of the image's applications. ${ }^{9}$ Our distance from fundamental truths could also be illustrated in terms of society's dependence on poets like Homer as the source of all wisdom, as Socrates will show in Book Io when he ranks poetry at two removes from reality, closely mimicking the cave's ontological and epistemological hierarchy.

But for our present inquiry it is more appropriate to concentrate on another educational topic suggested by the Republic itself, namely, education about justice.

That the cave is to be interpreted as illustrating, among other things, the abysmal incomprehension of justice among nonphilosophers becomes clear when the returning philosopher, dazzled by the outside light, can no longer see properly, and anyway no longer takes seriously the guessing games that the prisoners play about the sequence in which the shadows will appear. As a result he looks ridiculous and incompetent to the prisoners, who warn against anyone else following the example he has set and who would kill him if only they could get their hands on him $(7.5 \mathrm{I} 6 \mathrm{e}-5 \mathrm{I} 7 \mathrm{a})$. That is, a philosopher in an ordinary city will inevitably look dangerously unworldly, because his mind is on higher things. And where does he manifest this apparent unworldliness? Socrates describes him as cutting a poor figure "when forced, in the law courts and elsewhere, to contend about the shadows of what is just or about the statues whose shadows they are, and to enter debates about this [i.e., about what is just] using the assumptions about these things made by people who have never seen Justice itself" $(7.5 \mathrm{I} 7 \mathrm{~d}-\mathrm{e})$. It is clear that a democratic city like Athens is envisaged, in which both in the law courts "and elsewhere" -meaning such political contexts as the assembly and council - the citizens engage in debates about what decisions will be just. The special focus on the law courts is explained by the oblique authorial allusion to Socrates' own future trial and condemnation. For Socrates was not known as a regular participant in

9 Briefly, I take it that the prisoner's turning round to look at the statues and other manufactured images would represent the sensory pursuit of mathematics, as illustrated in the Meno; that the shadows and reflections outside the cave represent mathematical intermediates, that is, perfect intelligible images of mathematical Forms; and, of course, that the objects casting those reflections symbolize the mathematical Forms themselves. 
discussions at the assembly or council. It is natural that Plato should want to put the focus instead on the Athenian law courts, where Socrates, for all his intellectual brilliance, was unable to secure himself an acquittal and where his fellow citizens, or in the language of the allegory his fellow prisoners, did indeed manage to get their hands on him and kill him. The parable thus represents, among other things, the Athenian democracy's treatment of the paradigmatic philosopher.

But I have jumped ahead to the story of the returning philosopher. Let me go back and ask about his original release from the cave. In the courts and assembly, we have seen, they argue about "the shadows of what is just or about the statues whose shadows they are." If the shadows constitute the whole of their experience, how can the prisoners argue about the objects casting them as well? To see why it is put this way, we must ask what the statues and shadows represent in the case of justice. The relevant statues in this part of the allegory are those depicting whatever item outside the cave symbolizes the Form of justice. In which case what these man-made statues stand for more specifically are human acts or decisions that mimic the true nature of justice with sufficient success to merit the predicate "just," albeit still incompletely, as Plato's metaphysics requires. The regular guessing games about which shadow will come along next might symbolize, for example, a debate in the assembly as to whether a proposed decree is just. Behind the prisoners are one or more statues representing the genuinely just decision to take in this situation; but all that the prisoners see are the shadows, or inadequate pretenses, of it that are danced in front of them by unscrupulous orators. ${ }^{10}$ Normally, then, in both the assembly and the courts, the

10 In saying this, I do not mean to identify these orators, demagogues, sophists, and other manipulators with any individuals portrayed in the cave simile. They cannot easily be equated with either $(\mathbf{I})$ bound prisoners (if they were, how could they control the shadows?) or (2) the mysterious people carrying the manufactured images (or they would turn out to be, contrary to Plato's conviction, the most enlightened people in the city, uniquely able to tell real instances of justice from their fraudulent imitations). If (2) have any secure identity, they might be gods or daimons, conveying to us dependable guidance that we choose to ignore, or more plausibly the established laws of the city, which from Crito to Laws Plato tended to credit with an at least semi-authoritative status (an authority linked at Laws 7I3C-7I 4a to that of daimons). As for orators and their ilk, it is safer to conclude that the imagery does not specifically cater to them. 
arguments must be limited to being about the shadows. If the debate might sometimes extend to talk about the statues too, as Socrates indicates, the natural explanation is that this represents an attempt by an enlightened speaker, like the returning philosopher, to raise the level of discussion above the rhetorical fictions that are jostling for attention. If so, this talk will, sadly, fall on uncomprehending ears.

How the future philosopher is first released is left mysterious in the cave simile. This silence is understandable, because the answer would be very different in an ideal and a nonideal city, both of which are represented by the simile at different points. In an ideal city, the education system itself will bring about the release of the suitably gifted. In a nonideal city, there is nothing about the civic conditions as such that can account for the emergence of a philosopher $7.5 \mathrm{I} 9 \mathrm{a}-$ b), so Plato is wise not to supply any symbolism for it. But we may guess that this incipient philosopher is already, while still tied up, refusing to play the games about justice that the assembly and law courts encourage, and instead insists on working out for himself what is just in each situation. By doing so, that is, by looking for the genuinely just act or decision behind the oratorical façade, he is already inserting into the talk about shadows some hypothetical reference to the objects that may be casting them. What, then, would be more natural than that, if he finds a way, he should force himself to turn round and look at those objects? Insofar as Socrates' own life is the model for the prisoner's escape, we may think once more of his characteristic insistence, when confronted with unlawful pressures, on making his own independent assessment of what action was just. ${ }^{11}$

At this stage of his release, although now free, our emerging philosopher is still inside the cave, that is, operating within the confines of the sensible world, dealing only with the merits of particular cases of justice and injustice. ${ }^{12}$ But it is almost inevitable that he

11 Notably, Ap. 32a-e.

12 Although, within the ideal city, this phase bears some resemblance to the fifteen years of practical administrative experience scheduled for the trainee rulers (7.539e-540a), it differs in coming before, rather than after, their fifteen years of higher education. It therefore corresponds rather to their initial education, up to the age of twenty, as described in Books 2 and 3, an education designed to maximize their exposure through reformed cultural media to genuinely good models and other influences. 
should next, however painful the transition may be, drag himself up into the outside world. For that world represents the world of Forms, and there alone can he seek the answer to the question that is now at the top of his agenda: what is justice?

Once in the intelligible world, we are told, he is at first so dazzled that he cannot look at the objects around him, one of which represents justice. All that he can manage is to look down at its reflection in a pool or its shadow on the ground. Only later will he be able to raise his eyes and look at the object casting this shadow or reflection, in other words, in our chosen example, to study the Form of justice directly in its own right.

What is represented by this intermediate stage, when shadows and reflections are all that he can directly contemplate? The shadows and reflections obviously enough symbolize images of Forms, but, since the region outside the cave represents the intelligible world, these will be intelligible images of Forms, not sensible images such as the statues and other manufactured replicas inside the cave must stand for. The shadows' ontological superiority to the statues is conveyed not only by this difference, but also by the fact that they are depicted as natural rather than merely artificial images. Admittedly, the manufactured images in the cave and the shadows and reflections outside are alike to the extent that both represent direct images of Forms; and the mathematical fact - never explicitly mentioned, but surely known to $\mathrm{Plato}^{13}$ - that the two middle sections of the line (pistis, "trust," and dianoia, "thought") must be equal reflects this partial metaphysical parity between their respective objects, I suggest. Nevertheless, the escaped prisoner's upward move from sensible to intelligible images of Forms undoubtedly represents intellectual progress, and our next task is to work out what that consists in.

Now a sensible image of the Form of justice would be exemplified by a person, like Aristides, or a city, such as Sparta, judged to deserve the epithet "just," but still with an unavoidable compresence of injustice. ${ }^{14}$ For according to Platonic metaphysics all sensible particulars suffer from this deficiency, whereby they never participate

13 On this point, and for an account of the Line, see N. Denyer's chapter I I in this volume.

14 Cf. $5 \cdot 479 \mathrm{a}-\mathrm{b}$. 
in one Form without also participating, in some respect, in the opposite Form. That is precisely the reason why, in Plato's eyes, no study of particular cases of a given property can ever lead all the way to knowledge of that property in its own right.

We can infer, then, that the reason why the progression from seeing statues inside the cave to seeing shadows and reflections outside it represents an advance in understanding is that it corresponds to progress from studying justice through sensible instances, for example, by investigating an individual imperfectly just state like Sparta, to studying it through an intelligible instance. What could this latter be? A satisfying answer is provided by the procedure that has already been followed in Republic 2-4 for arriving at a definition of justice. For that definition was sought and found by first constructing and examining an idealized exemplar of justice: a perfect image of the Form of justice, namely, the ideal city. The ideal city is not itself the Form of justice, ${ }^{15}$ and indeed it manifests justice no more than it does all the other cardinal virtues. However, thanks to not being a sensible exemplar, and thus not restricted by the usual limitations of sensible instantiations of Forms, it is perfectly just, as well as perfectly wise, and so on (4.427e; cf. 5 OId). Because of this perfection, it proved possible in Book 4 for Socrates and his interlocutors to read off from it the definitions of those virtues in a way that would have been impossible when looking at, for example, a Sparta or an Athens and seeking to disentangle its just aspects from its unjust aspects. When our escaped prisoner finally raises his eyes from the shadow or reflection of justice to the Form itself, he is making exactly that move, working from a perfect intelligible model in order to arrive at the definition of the Form of justice.

He has still not finished his education about justice, however. The escaped prisoner lets his eyes, now used to the light, travel further, not only over the beings all around him, but up to the heavenly bodies, until finally he can look at the sun (representing the Form of Good), in the light of which he now fully understands the new world around him for the first time.

Actually, it seems a credible conjecture that a value Form like justice, being so closely akin to goodness (the sun) itself, is represented

15 See Burnyeat I992. He argues, rightly, that the Republic's ideal city is not a Form at all (pp. 298-99 of the reprint). 
by one of the heavenly bodies (cf. $5 \mathrm{I} 6 \mathrm{a}-\mathrm{b})$, rather than by one of the terrestrial beings populating the region outside the cave. If so, the ship simile and the cave simile come together at this point: in both, the heavenly bodies symbolize those entities - the moral Forms by reference to which the philosopher alone would be able to govern the city.

There has been much debate and uncertainty as to why the Good is supposed by Plato to have the role of making the other Forms intelligible. The majority of scholars believe that goodness is a concept presupposed by, and therefore required for understanding, the "ideal" properties that the Forms possess qua Forms, in particular, their perfection. ${ }^{16} \mathrm{I}$ doubt whether this is either linguistically or philosophically the best answer. Linguistically, it is questionable whether "good" (agathos) - rather than, say, "perfect" (teleios), "pure" (eilikrines), or "correct" (orthos) - is a natural Greek word for the kind of perfection with which Forms exhibit the properties they stand for. Philosophically, the progress of the prisoner escaping the cave has given us reason to think not only that an ideal exemplar is as good or perfect a model of F-ness as the Form is, but that it can be grasped in its perfection even by someone who does not yet know the Good itself. Besides, Forms have other, equally important ideal properties, such as unity and eternal being, leaving it even less clear why perfection in particular should be singled out. ${ }^{17}$

Rather, I take it ${ }^{18}$ that goodness stands over other Forms because it accounts for the proper concept specific to each Form, be it justice,

16 This idea is much too widely advocated (or, in many cases, assumed) in the modern literature for me to document it here. The fullest articulations of it that I know are by G. Santas - see Santas I 980 and 200I, ch. 5 . It is particularly well developed by M. Miller (chapter $\mathbf{I} 2$ in this volume), and I am aware that in the space available I am doing less than justice to his account.

17 See note $2 \mathrm{I}$ below against the view that goodness is unity. If it were, then the view I am opposing might have to hold that goodness is what enables us to understand the uniqueness, rather than the perfection, of each Form. It is hard, however, to believe that Plato thinks the ultimate purpose of five years of dialectic lies in the need to understand what makes each Form one, especially when arithmetic already has unity as its special focus. For a more nuanced discussion of how goodness might relate to unity, see M. Miller's chapter 12 in this volume.

${ }^{18}$ My views on this have something in common with those of R. Patterson (Patterson I985) and of N. Denyer (chapter II in this volume), both of whom give a more richly teleological account of the Forms' goodness than the majority of interpreters. 
largeness, oddness, or (possibly even) man. Take justice first. Even if you have successfully formulated a definition of justice, you don't fully understand it until you have worked out what makes justice good. ${ }^{19}$ Since justice is a value, the point is a readily intelligible one: no one, it might be said, could fully understand any given value without even knowing what goodness itself is. Although Republic 4 has already formulated a definition of justice, we were there told by Socrates that his route to it was a shortcut $(435 \mathrm{c}-\mathrm{d})$, and in Book $6(504 \mathrm{~b}-\mathrm{d})$ he made it explicit that the "longer route" which was thus avoided would have been one via the Good. Thus the dialogue's definitional task regarding justice was not really completed in Book 4 , and could not be completed by anyone who had not first reached an understanding of the Good itself - a task that according to Socrates requires ten years of preparatory mathematical studies, followed by five years of dialectic, culminating in a fully defended analysis of the Good. Only people with that level of education - an elite to which Socrates protests that he does not himself belong $(6.506 \mathrm{~b}-\mathrm{c})-$ could expect to understand not only what justice is, but, given that justice is as the definition says it is, precisely how it reflects or embodies goodness.

Seeing why justice should be thought to be fully intelligible only in the light of goodness is in fact a relatively easy task. Seeing why the same is true of man (if there is such a Form) should also not prove too problematic: if a human being is to be understood in terms of a divinely ordained function, as Plato holds, and if that function is, in effect, the Form of man, the Form will be understood fully only by someone who has internalized the lessons of the Timaeus sufficiently to understand the good served by the existence of human beings. Similar conclusions may be drawn even about the Forms of artefacts, introduced in Book ro (596a-b), assuming that these have functions subordinate to the human good.

What has proved much more puzzling is why mathematical Forms, such as odd and even, are likewise assumed to be intelligible only in the light of goodness. The most promising solution, in my view, has been to recognize that Plato's account of the Good would itself have been a highly mathematical one. ${ }^{20}$ This is attested by the

19 Cf. 6.506a.

20 E.g., Cooper I977, p. I44 of the reprint. 
near-contemporary accounts of his public lecture on the Good, in which he was said to have disappointed his audience by speaking largely of mathematics, and ended up saying something reminiscent of the Philebus account of the good in terms of limit and measure, probably that "the Good is a unification of limit." ${ }^{21}$ If discussions in the Academy viewed the Good as something like an ideal proportionality, intelligible only through the conceptual framework of a highlevel mathematics, many things are explained, among them $(\mathrm{I})$ how Good might be the ultimate explanatory principle even for mathematical entities, while (2) also accounting for such values as Justice (which, appropriately, Socrates at $4.443 \mathrm{c}-444$ a has represented as itself a kind of harmony), (3) why he takes it as read that understanding of the Good would require a preliminary ten-year period of mathematical study, culminating in harmonics $(7.522 \mathrm{~b}-53 \mathrm{Ic})$, and (4) why no definition of the Good was ever going to be formulated in an essentially nontechnical dialogue such as the Republic is. ${ }^{22}$

We are now in a better position to clarify what kind of knowledge Plato's philosophers bring to the art of government, and how radically it distinguishes them from the benighted prisoners in the cave. In its essential character it is mathematical knowledge, albeit at a level higher than any of the individual mathematical sciences. Its focus is the mathematical principles of proportionality on which all lower values ultimately depend. I suspect that, but for the dominant imagery of the cave, the mathematical content of these values would have been seen to extend much further down the chain of

21 Aristoxenus, Harm. II I, pp. 31.20-3I.2 Meibom: kai to peras hoti agathon estin hen: like some others (e.g., Popper I966 [1945], p. I46; Guthrie 1978, p. 424), I take to peras ("limit") to be part of what Plato said, and not just an adverbial expression meaning "to cap it all." For the definition of good as a unification of items previously identified with peras, see esp. Phil. 65aI-5. Although I have learned much from Burnyeat 2000 , I doubt the specific view he and others defend that in Rep. the Good is identifiable with unity. I do not believe that Plato would have written about "the One itself" as a special object of arithmetic (7.524d-525a) if he had at the time of writing identified something of that same name with the unhypothetical first principle whose study stands above all the mathematical sciences. Undoubtedly, the unity of the city is, as Burnyeat rightly emphasizes, of paramount importance to its well-being, but proportionality is itself in turn the proper basis of a thing's unity; cf. Tim. 3 Ic, "The finest of bonds is whichever does most to unify itself and the things it binds, and proportionality [analogia] is the naturally finest producer of this."

22 Likewise, the Philebus, whose main focus is on an ideal exemplar of goodness, the good life, rather than on the Good itself. 
transmission than the text of the Republic makes explicit. For example, an understanding of justice informed by a prior understanding of the Good would be far more technical and mathematical than the broad-brush sketches of civic and psychic harmony developed in Book $4 .{ }^{23}$ As early as the Gorgias Plato's Socrates had attributed Callicles' moral ignorance to his neglect of mathematics, there explained as his failure to appreciate the power of "geometrical equality," a principle of just distribution in proportion to individual deserts that might well be expected to enter into the detailed decision-making of Callipolis. ${ }^{24}$

With due caution, we might compare economic science and its acknowledged indispensability to good government in the modern world. Comparably, in Platonic ethics mathematical thinking is not just a propaedeutic training for philosophical dialectic about values, but stands at the very heart of the discipline's methodology. This is by no means to suggest that all the detailed decision-making in the ideal city will be mathematical in form. But there is good reason to assume that the first principles invoked and applied in the course of decision-making would regularly exhibit mathematical features. ${ }^{25}$

Plato's Socrates never suggests that theoretical understanding of the value-Forms is sufficient to make his philosophers successful rulers. For that they need an appropriate all-round physical, cultural, and military education (Books 2 and 3 ), and a great deal of practical administrative experience as well (7.539e-540a). The thesis we have been examining up to this point is only that a high-level theoretical understanding of values is a necessary condition of skill in government. That, however, is already enough to generate the wellknown problem to which I devote the second half of the chapter: why, given that they must possess this high-level theoretical understanding before becoming rulers, should philosophers want to spend their time on the practicalities of government?

23 The only hint of this in Rep. is at $9.587 \mathrm{~b}-\mathrm{e}$, the half-serious calculation that the just life is precisely 729 times pleasanter than the unjust.

24 Grg. 508a, with the note ad loc. of Dodds I959; cf. Laws 757 b-c. How Plato might envisage proportional equality at work in his ideal city can be glimpsed, albeit without the mathematics, by comparing the randomly equal distributions characteristic of a democracy, at $8.558 \mathrm{c}$, with the proportionate principles of distribution assumed at $4.433 \mathrm{e}-434 \mathrm{~b}$.

${ }^{25}$ For judicious discussions of the role of mathematics in the philosophers' training, see esp. Ferrari 2000, pp. xxix-xxxi, and Burnyeat 2000. 


\section{WHY PHILOSOPHERS WILL UNDERTAKE TO RULE}

In Book I, long before the idea of designing Callipolis has even been broached, Socrates' conversation with Thrasymachus is interrupted by an exchange with Glaucon. The exchange eloquently anticipates the conversation in the later books where the education of a ruling elite is worked out in detail by these same two, Socrates and Glaucon.

In the Book I passage, Socrates remarks to Thrasymachus that ruling, like any expertise, is essentially altruistic, and that this is why those who undertake it have to be rewarded either with money or with honor, or compelled by the threat of a penalty. Glaucon butts in to ask for an explanation of this third option, compulsion by threat of penalty. Socrates replies that money and honor are not motivations for the very best people, and continues (I.347b-d):

For this reason, neither for money nor for honour are good people willing to rule. For they don't want either to exact payment for their office openly, so as to be called mercenary, or to get it furtively from the office they hold and to be called thieves. Nor do they rule for the sake of honour, not being honour-lovers (philotimoi). So they have to have compulsion (anankē) and penalties applied, if they are going to be willing (ethelein) to rule. That's why voluntarily taking on office without waiting to be compelled is liable to be considered unworthy. The greatest penalty is that of being ruled by one's inferior, if one is not willing to rule. This is the penalty that decent people seem to me to be afraid of when they discharge the offices of government, and when that happens they enter into government not as if they are embarking on something good or are destined to find it a good experience, but as something they are compelled to do and on the ground that they don't have equals or superiors to entrust with the task. For the probability is that, if a city of good men were to come into being, they would vie with each other not to govern, just as at present people vie to govern, and that it would then become plain that it is not in the nature of a real ruler to look to his own advantage, but rather to that of his subject.

It is extraordinary how intricately this exchange showcases the later developments of the dialogue. ${ }^{26}$ The question of what could possibly motivate the best people in a city to undertake government is broached in a way that already draws on the three-class structure that is developed in the later books, where the lowest or mercenary class is motivated by the money-loving part of the soul, the

26 Cf. Kahn i993, p. I38. 
military class by the honor-loving part. This psychology will leave no puzzle at all as to what might motivate members of the two lower classes to take on political office, should the opportunity arise: there is after all plenty of cash and plenty of honor to be earned by ruling. But, Socrates is arguing, there is no analogous reward on offer to the best people, since nothing that they want is provided by the activities of government. And since no possible enticement could persuade them to rule, they would instead have to be compelled by threats. Fortunately, however, the most effective such threat is one that imposes itself more or less automatically: it consists in the fact that, being ex hypothesi the best people in the city, if they decline to rule, they will have to put up with being ruled by others worse than themselves.

It is worthwhile to pause on the assumptions underlying these remarks.

First, although the ideas here map fairly accurately onto later developments in the Republic, Socrates' argument relies at this stage on appeals to experience and to received views. Whereas in later books, once the "best" people have been unmasked as philosophers, it will be judged problematic how their fellow citizens could actually want them to rule, at the present stage they are characterized with sufficient looseness to keep any such difficulty hidden. Socrates' claim is the ostensibly empirical one that in existing societies, when good people take on office, their motivation is the selfish one of avoiding subordination to their inferiors. We are, to this extent, not yet in the theory-driven world of an ideal city. Nevertheless, it is in the lines I have quoted that that celebrated thought-experiment gets its very first airing, ${ }^{27}$ when Socrates envisages an imaginary city of good men, who are pictured as competing not to govern. From Socrates' passing utopian remark, combined with the anticipatory intervention of Glaucon, the passage gains a pronounced proleptic force. ${ }^{28}$ My plan, partly for this reason, is to use the passage as a lens through which to investigate the dialogue's later provisions concerning philosophical government.

27 Thus, e.g., Adam 1963 [I902], ad loc.: "the first express allusion to an Ideal City in the Republic"; his wording "an Ideal City" rightly allows for the fact that the ideal city depicted in later books differs in not consisting entirely of uniformly good individuals.

28 Cf. Kahn I993, and, more generally, Kahn 1996. 
But as well as being forward-looking, the passage is also a vital bridge from Socratic to Platonic thought. Quite apart from its location in the highly Socratic opening book, when it identifies as a "penalty" the prospect of being ruled by one's own inferiors it is building on a distinctively Socratic theme. For the Socrates of the Apology very uncharacteristically claims knowledge of a closely related thesis, namely, that it is wrong to disobey one's superior, man or god $(29 \mathrm{~b})$. Although the grounds of this knowledge claim have become a subject of controversy, I am inclined to assume that Socrates takes it as guaranteed true by the meaning of its own terms: if someone is better than you, it goes without saying that that person's judgment as to how you should conduct yourself outweighs your own. However construed, the grounds for the Apology thesis that it is bad to disobey your superior are likely to be identical to those of the Republic thesis, that it is bad to have to obey your inferior.

My next question is what, in this essentially Socratic approach to the art of ruling, is the role played by altruism? On the one hand, Socrates is emphatic (I.346d-347a) that any expertise (techne) , be it ruling, medicine, or building, is essentially altruistic in character and purpose. On the other, he does not trace that altruism back to any moral or other feature of the art's practitioner qua human being. If you become a ruler, you are ipso facto committing yourself to promoting the good of your subjects; but, as the above quoted passage makes plain, absolutely nothing commits you to becoming a ruler. On the contrary, if you do choose to become a ruler, that will be because you have calculated that, at least by comparison with your other options, it is in your own best interests. And this self-interested calculation is envisaged as incorporating the assumption that ruling is not per se the best activity a good person could engage in. What better activity ruling might come second to is not indicated, but the silence is one that Book 7 will amply rectify.

What seems to me most significant, in view of later developments, is the following. That there should be something better to do than rule is not at this early stage in the discourse introduced as an inconvenient contingency that somehow has to be catered for. On the contrary, Socrates' point is that, in the interests of good government itself, things have to be so set up that there is something better that 
the ruler could have been doing. ${ }^{29}$ For - so Plato's great political insight runs - the only good ruler is a reluctant one.

This reluctance is expressed in terms that deserve careful note: "so they have to have compulsion and penalties applied, if they are going to be willing to rule" (I.347c). On the one hand, good people will need to have "compulsion" (ananke) applied to them in order to get them to rule. On the other hand, as a result of this compulsion they will "be willing" (ethelein) to rule. The envisaged compulsion, that is, is not brute force operating against their better judgment, but the force of circumstances that makes the decision to rule, although not their preferred choice, one into which after weighing up their options they enter freely. Likewise the envisaged willingness does not express their absolute preference, but their acceptance of the compulsion that circumstances are exerting.

It is in Book 7 that these same concerns most recognizably return to the surface. The citizens equipped to rule best have by now been identified as philosophers. And thanks to the elaborate depiction of the philosophers' education we by this stage know a great deal about the skills and interests that will ensure that, on the one hand, they are uniquely equipped to rule but, on the other, they would have preferred not to. Their ruling skill depends primarily on their acquaintance with the Forms, thanks to which they alone understand and can impose the values that make for a just society. But their true passion is for a purely contemplative life devoted to dialectical reasoning about the Forms, undiluted by the less fulfilling political activity of applying the fruits of that knowledge to the merely human society in which they live.

The notorious puzzle that this gives rise to is why Socrates appears confident that the philosophers in his ideal city will actually agree to rule. He has compared their dialectical activity, dealing with Forms alone, to life outside the cave, their ruling activity to a return to the murky depths to order the lives of those less fortunate than themselves; and this has made it obvious to Glaucon that the political life is less fulfilling for them than the contemplative. Glaucon

29 Thus ruling is, in terms of Glaucon's threefold division of goods (2.357a-d), best treated as a type (3) good, one like medical treatment, valued only for its consequences and not for its own sake. For the relation of Glaucon's schema to the current question, cf. R. Weiss's chapter 4 in this volume, section 4 . 
accepts Socrates' prediction that they will nevertheless obey the command to participate in government, citing by way of explanation the fact that they are just $(7.520 e)$. But the problem is that justice has in Books 2-4 been recommended as preferable because in the agent's own interest, whereas here we have a case where the philosophers' just act is conceded not to be in their best interest. The just act involves choosing a less happy life in place of a supremely happy one. Yet, it is predicted, they will choose it.

This has become a celebrated crux, one on whose solution entire reinterpretations of the Republic have been founded. I propose to lean on its antecedent in Book $\mathrm{I}$ in order to narrow down the possible solutions, before developing what I take to be the correct one. If the solution I shall advocate is right, the text of the Republic is entirely and unproblematically consistent in the matter.

First, we may doubt any interpretation according to which sheer moral goodness or understanding is sufficient to motivate the philosophers to take on office. ${ }^{30}$ Certainly, the starting position in Book I, as we have seen, discounted that option, it being only when one has already undertaken a craft, be it that of medicine or of ruling, that its altruistic practice becomes an actual commitment. Has anything changed relevantly since then? It seems not, ${ }^{31}$ because the same terms are used systematically to describe the philosophers' predicament in Book 7 as we encountered in Book I. Their preference for a nonpolitical life is, far from being a disqualification, the reason par excellence in favor of requiring them to rule $\left(\mathrm{I} .347 \mathrm{~d}_{i}\right.$ $7.52 \mathrm{Od}, 52 \mathrm{Ib})$. Getting them to rule will require compulsion ( $\mathrm{I} .347 \mathrm{c}-$ d; 6.499b-c, 5ood; 7.5 I9e, 520a, e, $52 \mathrm{Ib}, 539 \mathrm{e}, 540 \mathrm{a}, \mathrm{b})$, but in the circumstances they will nevertheless "be willing" (I.347c; 7.520d) to make the sacrifice.

30 E.g., Irwin I995, sec. 213; Kraut I99I.

${ }^{31}$ In Book 4 the trainee guardians are selected partly for their belief that the city's interests are identical to their own $(4 \mathrm{I} 2 \mathrm{~d}-4 \mathrm{I} 3 \mathrm{~d})$. Has this not, then, separated the ideal city's rulers from the self-serving potential rulers considered in Book I, and ensured that they are single-mindedly motivated to undertake government? It seems not. Although their belief about identity of interest made their initial training much easier, it was never said to be true, let alone knowledge, but repeatedly just a "belief"; and their eventual preference for philosophy over ruling, as this emerges in Book 7, seems enough to show that the belief was not one that they could still be expected to hold by the time they were fully educated. 
What some interpreters believe to be a relevant change between the two passages is the introduction of moral Forms in Books 5-7. These, it is suggested, provide new motivating factors for those few - the philosophers - who have cognitive access to them. In particular, use has been made of $6.500 \mathrm{~b}-\mathrm{d}$, where the philosophers are described as naturally inclined to imitate the intrinsic orderliness of the Forms so far as they are able, explicitly including the imposition of demotic virtue on the souls of the citizens. But the passage is carefully cast in the same terms of "compulsion" that we have already repeatedly met: the philosopher is indeed bound to imitate in his own soul the orderliness of the Forms, but as for his imposition of some semblance of that same order on the souls of ordinary citizens, this is described as what he will aim to do "if some compulsion [anankē] arises" for him to apply his knowledge of Forms to others, and not simply to himself (5ood).

An alternative, or complementary, way of securing the desired result, albeit this time without any very specific textual support, has been to point to the Form of the Good as the new motivating factor that transforms philosophers into pure altruists. In particular, it is sometimes remarked that the Form of the Good is absolute good, not someone or other's good. Correspondingly, it is argued, the philosophers' supreme desire can no longer be for their own good, but simply for the maximization of good wherever the opportunity presents itself. $^{32}$ I do not think there is adequate evidence anywhere in the Republic for this account of moral motivation. ${ }^{33}$ True, the Good itself is an absolute value, not anyone's individual or collective good. But that is simply because it is a Form. Likewise, the large itself is pure largeness, not anything's largeness and not largeness relative to this or that comparand. Nevertheless, largeness itself can never be imposed on the world other than as something's largeness

32 Mahoney 1992 (esp. p. 280, "the desire for the unrestricted good") ${ }^{\prime}$ Cooper I977; Annas I981, ch. I0; Miller I985; Parry 1996, esp. ch. 4.

${ }^{33}$ Even at 540a-e, a passage rightly given special emphasis by Parry I996, pp. 2 I I-I 3 , the motivating force of the Good is subordinated to the familiar need to "compel" the philosophers to act with it as their model (540a). Better evidence might seem to lie in the Timaeus, where the Demiurge's motivation is simply his wish for everything to be good (29e-30a, cf. Parry I996, pp. 202-3). But that is a very special case, in that the entire universe is already the object or domain of his craftsmanship. It therefore holds no implications for the domain that a lesser expert, such as the human philosopher, would be likely to choose. 
relative to one or more other things. And exactly the equivalent goes for goodness itself as well. Thus there is no reason to suspect that the philosophers' acquaintance with goodness as a pure Form changes the parameters for its imposition on the sensible world or, in particular, that it erases whatever initial preference they may have for their own good.

There remains the fact that the philosophers are just and that their justice is cited as a motivating factor for their agreement to govern. However - a point too often overlooked - the fact that they are just is mentioned by Glaucon not as a reason why they will want to rule, but why they will be willing, that is, why they will not actually disobey the order to do so. The lesson of Book I, that willingness is a notion that for Socrates can operate even when acting under compulsion, crucially helps in clarifying this. At $520 d-e$ the following exchange takes place:

"Will our protégés disobey us, do you think, when they hear this, and not be willing to take their own individual turns at sharing in the city's work, despite most of the time dwelling with each other in purity?"

"Impossible," said Glaucon, "since we will be giving just orders to just people. But the main point is that each of them will approach ruling as a necessity - the very opposite of those who currently rule in each city."

Thus the philosophers' justice contributes to the explanation of their decision only to the extent that it throws light on the precise notion of compulsion that is being deployed. And I suggest that the missing assumption is the following. Just people could never be compelled to perform an unjust act, because they would sooner face death, as Socrates $^{\prime}$ conduct testified when he was ordered to take part in an unjust arrest (Ap. 32c-e). They can, on the other hand, be compelled to perform just acts. And that alone is the point on which Socrates and Glaucon are agreeing.

Nor should we worry that an alien notion of justice has somehow intruded, when the philosophers of Callipolis are told $(520 \mathrm{a}-\mathrm{c})$ that, unlike self-taught philosophers in nonideal cities, they owe a debt to their city for their education and that their repaying it is therefore just. True, there is a strong resemblance to Simonides' notion of justice as repaying what you owe, discussed in Book I and rejected there with the counterexample of unjustly returning a weapon owed to someone who has in the meantime gone mad (I.33 IC, 33 I C-332a). 
But what is being invoked is actually a revised version of that view, and one accommodated to the Book 4 definition of justice as psychic harmony. For when testing the Book 4 definition, Socrates gave a list of "vulgar" examples (4.442e4-443aI I), the first and most elaborately worded of which was that someone with psychic harmony would be unlikely to refuse to return a deposit (though not explicitly that he would never do this):

For example, if we had to agree about that city, and about the man with a nature and nurture that compare with it, whether someone like that seems the sort who after receiving a deposit of gold or silver would withhold it, who do you think would expect him, more than they would expect those who are not of his kind, to behave that way? ${ }^{34}$

This picks up the example of returning a "deposit" used in the Simonides critique (I.33 Ie-332a) and takes account of that early discussion by being formulated cautiously enough to allow for special circumstances in which even the Platonically just person would refuse to repay what he owes. In this it also anticipates the serious possibility that philosophers in Callipolis might, while remaining just, find reasons not to repay their education. ${ }^{35}$ But reminding them of the intrinsic Platonic justice of the act - its being the characteristic behavior of a Platonically just soul - is at least sufficient to ensure that they won't resist compulsion, as they would if the act were unjust.

Admittedly, it is notoriously unclear exactly why Socrates and Glaucon so readily agree in Book 4 that the Platonically just person

34 The translation "more than they would expect" is what underlies my paraphrase "unlikely to refuse"; indeed, many translators so render the passage as to make degrees of likelihood explicit, e.g., Griffith in Ferrari, 2000: "Could anyone . . . imagine such a man to be more likely to do this than people who were different from him?" (similarly, Jowett, Shorey, Reeve, and others). An alternative rendition, "rather than those who are not of his kind" (e.g., Leroux, Grube and Reeve, Bloom), would make the assertion less qualified, allowing the possibility that the Platonically just man would never withhold a deposit; but even then the degree of expectation conveyed by "who do you think would expect him ...?" would remain considerably weaker than in the examples that follow at 443a.

35 When at 7.520 Glaucon called it "impossible" that the philosophers would refuse to rule, that was explicitly the impossibility of just people refusing to obey a just order. The possibility that in other circumstances they might refuse to repay a debt would have to represent a case where doing so was unjust, as in the example of returning a knife whose owner has gone berserk. 
would typically repay a deposit. ${ }^{36}$ But that is a problem for the interpretation of Book 4, and should not be allowed to cast doubt on the fact that the justice that in Book 7 plays this subordinate role in inducing the philosophers to return to the cave is Platonic justice as analyzed in Book 4.

We are thus brought back to the dominant and constantly repeated notion of compulsion as the key to understanding why the philosophers agree to rule. And here once more we can hope to gain illumination from Book I's anticipation. The references to compulsion in Book 7 indicate that "we" - Socrates and his fellow utopian theorists - will "compel" the philosophers to rule. ${ }^{37}$ But what form will the compulsion take in Callipolis itself? Who or what will replace these external legislators? Here, where Book 7 is silent, Book I is eloquent. The compulsion that drives the best men to rule is there explained, not as a coercion institutionally applied by threats and other forms of political leverage, but as consisting in the stark nature of the choice that faces them. For if they decline to govern, they will suffer the worse fate of having to be ruled by their inferiors. And therein lies the real compulsion. Once we recognize that the Book I preview has not been superseded but is still operative in Book 7, we may usefully draw on it to inform our reading of the "compulsion" emphasized in the latter book. ${ }^{38}$ What really makes it inevitable that the philosophers will shoulder the unwelcome duty of government is their recognition that, were they not to do so, they would no longer live in an ideal city, and would instead be subject to the rule of nonphilosophers, their own inferiors. That compulsion by circumstances, operative since Book $\mathrm{I}$, is not in Book 7 replaced by some new motivation for undertaking to rule; all that Book 7 adds is the reason why the philosophers will not resist the coercion that they face, as in other circumstances they might have done. ${ }^{39}$

36 The classic formulation of this problem is that of Sachs 1963.

${ }^{37}$ Hence at $7.5 \mathrm{Ige}$ it is by "law" that philosophers are required to rule.

38 Brown 2000 , pp. 8-9, puts all the emphasis on compulsion by the external legislators, but his list of passages on "compulsion" (both there and at pp. 5-6) lacks the crucial Book I passage. Despite this particular disagreement, I am largely in sympathy with Brown's findings.

39 For example, the Socrates-like philosophers described at 7.520 , who do not owe their education to their cities, by implication choose to accept rule by their inferiors rather than govern. But why was the threat of rule by their inferiors not sufficient to compel them? The reason may well be the impossibility of their participating 
Is this too reductive an interpretation of "compulsion" to project forward into Book 7? It does not, for one thing, yet deal with the danger that any one philosopher might become a free rider, opting out of government but still enjoying the benefits of rule by his or her equals. ${ }^{40}$ Here at least it may seem preferable for the "compulsion" to be understood as a constraint legally enforced by the constitution, and not as in effect reducible to the force exerted by a reasoned choice between alternatives. In reply, we might borrow another sound bite from the Book I passage: in a city of good men, Socrates maintained there, there would be a competition to get out of ruling, just as there is now to rule $(347 \mathrm{~d})$. It is easy enough to envisage the system described by Socrates in Book 7, whereby the philosophers take it in turns to govern, but also not to govern, as the rational settlement they come to among themselves.

In ways such as this, we can narrow if not eliminate the gap between the two interpretations of "compulsion": the coercive sense in which it designates the apparently external enforcement of structures on the ideal state and the more benign one signifying the rational choices that its citizens make and abide by, given all the factors and circumstances that constrain their options. Compulsion is a notion that is called for above all when creating an ideal city out of a preexistent nonideal community. But internally to the running of such a city, compulsion in this strong sense becomes largely redundant, and easily gives way to its weaker but more benign counterpart advertised in Book I, namely, enforcement by the dictates of prudential reason. ${ }^{41}$

effectively in the local form of government without committing injustice. If so, considerations of justice - the absence of a debt to repay, added to the danger of acting unjustly in government - can on occasion motivate philosophers to resist the compulsion, whereas in the ideal city it motivates them on the contrary to accede to it.

40 Cf. White I986, p. 25.

${ }^{41}$ My thanks to many participants in the September 2004 Berkeley conference for helpful discussion, to Mitch Miller, John Ferrari, Malcolm Schofield, and Nick Denyer for an extremely rich array of subsequent written comments, and to Harry Adamson for discussion of the issues addressed in the second half of the chapter. I also presented papers with much of the same content at a conference held at Aoyama Gakuin University, Tokyo, in April 2004, and to an audience at UNC Chapel Hill in March 2006; I am grateful for the valuable discussions on those occasions too. 


\section{WORKS CITED}

Adam, J., ed. I963 [1902]. The Republic of Plato. Cambridge.

Annas, J. I98 I. An Introduction to Plato's Republic. Oxford.

Brown, E. 2000. "Justice and Compulsion for Plato's Philosopher-Rulers." Ancient Philosophy 20: I-I7.

Burnyeat, M. F. I992. "Utopia and Fantasy: The Practicability of Plato's Ideally Just City." In Psychoanalysis, Mind, and Art, ed. J. Hopkins and A. Savile (Oxford). Rpt. in Fine I 999c.

Burnyeat, M. F. 2000. "Plato on Why Mathematics Is Good for the Soul." Proceedings of the British Academy I03: I-82. Rpt. in Mathematics and Necessity, ed. T. Smiley (Oxford, 2001).

Cooper, J. M. I977. "The Psychology of Justice in Plato." American Philosophical Quarterly I4: I 5 I-57. Rpt. in Cooper I999.

Cooper, J. M. I999. Reason and Emotion. Princeton.

Dodds, E. R. I959. Plato: Gorgias. Oxford.

Ferrari, G. R. F., ed. 2000. Plato: The Republic, trans. T. Griffith. Cambridge.

Fine, G. I978. "Knowledge and Belief in Republic V." Archiv für Geschichte der Philosophie 60: I 2 I-39.

Fine, G. I 999a. "Knowledge and Belief in Republic 5-7." In Fine I999b.

Fine, G., ed. I999b. Plato I: Metaphysics and Epistemology. Oxford.

Fine, G., ed. I999c. Plato 2: Ethics, Politics, Religion and the Soul. Oxford.

Fine, G. 2003. Plato on Knowledge and Forms. Oxford.

Guthrie, W. K. C. I978. A History of Greek Philosophy, vol. 5. Cambridge.

Irwin, T. I995. Plato's Ethics. Oxford.

Kahn, C. H. I993. "Proleptic Composition in the Republic, or Why Book I Was Never a Separate Dialogue." Classical Quarterly 43: I 3 I-42.

Kahn, C. H. I996. Plato and the Socratic Dialogue. Cambridge.

Kraut, R. I991. "Return to the Cave: Republic 5 I9-52 I." Boston Area Colloquium in Ancient Philosophy 7: 43-62.

Mahoney, T. I992. "Do Plato's Philosopher-Rulers Sacrifice Self-interest to Justice?" Phronesis 38: 265-82.

Miller, M. I985. "Platonic Provocations: Reflections on the Soul and the Good in the Republic." In Platonic Investigations, ed. D. J. O'Meara (Washington, D.C.).

Parry, R. D. I 996. Plato's Craft of Justice. Albany, N.Y.

Patterson, R. I985. Image and Reality in Plato's Metaphysics. Indianapolis Ind.

Popper, K. R. I966 [1945]. The Open Society and Its Enemies, vol. I: The Spell of Plato. London.

Sachs, D. I963. "A Fallacy in Plato's Republic." Philosophical Review 72: I 4I-58. 
Santas, G. I980. "The Form of the Good in Plato's Republic." Philosophical Inquiry (Winter): 374-403. Rpt. in Essays in Greek Philosophy 2, ed. J. Anton and A. Preus (Albany, N.Y., I983), and in Fine I999b.

Santas, G. 200I. Goodness and Justice. Oxford.

Sedley, D. 2005. "Plato's Tsunami." Hyperboreus I I, no. 2: 205-I4.

White, N. I 986. "The Ruler's Choice." Archiv für Geschichte der Philosophie 68: 22-46.

Wilberding, J. 2004. "Prisoners and Puppeteers in the Cave." Oxford Studies in Ancient Philosophy 27: I $17-39$. 